\section{Neurosciences and dynamical system theory: some short remarks}

\author{
Giuseppe lurato* \\ Ministry of Education, Italy
}

\section{Abstract}

This very brief communication is aimed to highlight some recent contact points between neurosciences and dynamical system theory, passing through paleoneurology, with some remarks suggesting further possible interdisciplinary developments.

In [1], it has been considered some possible applications of non-equilibrium thermodynamics to biological systems, with a particular attention to evolution of human being, and making appeal also to socio-humanities (like anthropology, sociology, cliodynamics). From this interdisciplinary discussion, some other possible consequences, from the neuroscience side, have been drawn from either the ontogenetic and the phylogenetic standpoint. To be precise, considering formally human nervous system as a dynamical system, hence subject to thermodynamical roles and laws, it has been inferred possible ways by which climate changes, as well as meteorological variations, more or less may influence the normal and regular functioning of some basic biological components of central nervous system, above all forebrain structures, with a particular attention to hypothalamus. So, the paper argues on the possible relations between chief midbrain/forebrain structures of human brain and neuroendocrinological system, as influenced by climate changes and meteorological variations from the thermodynamical standpoint.

The hypothalamus is a fundamental forebrain structure which regulates the biochemical bases of human psyche, so it is a central component of psychosomatic system [2]. It may be considered as a particular dynamical system from the formal viewpoint, whose vital function is that said to be homeostasis, a crucial neurovegetative function; hypothalamus, with pituitary and endocrinological glands, gives rise to neuroendocrinological system but, at the same time, rules basic motivational and emotive functions as well as stress responses [3-11]. So, [1] considers, on the basis of what non-equilibrium thermodynamics says about the rapid variation of initial or boundary physical conditions (as occur in climate changes and meteorological variations), the neuroendocrine system (and the hypothalamus for first) as a dynamical system ruled by non-equilibrium thermodynamics, hence undergoing its rules and laws, from which then to infer

\begin{abstract}
More Information
*Address for Correspondence: Giuseppe lurato, Ministry of Education, Italy, Email: giuseppeiurato9@gmail.com
\end{abstract}

Submitted: September 01, 2021 Approved: September 23, 2021 Published: September 24, 2021

How to cite this article: lurato $\mathrm{G}$. Neurosciences and dynamical system theory: some short remarks. J Neurosci Neurol Disord. 2021; 5: 094-095.

\section{DOI: 10.29328/journal.jnnd.1001058}

Copyright: (c) 2021 lurato G. This is an open access article distributed under the Creative Commons Attribution License, which permits unrestricted use, distribution, and reproduction in any medium, provided the original work is properly cited.

\section{Check for updates \\ OPEN ACCESS}

possible explanations of certain neurological phenomenology, like meteoropathy. At the same time, in the paper has also been mentioned the possible relationships between human evolution and some chief notions of non-equilibrium thermodynamics, like entropy and the breaking of time symmetry, so pointing out their occurrence during the crucial bifurcation from primitive societies to civilized ones, which has besides given rise to the transition from a cyclic time to a linear one, typical of the modern societies.

On the one hand, if one looks at the neurobiological bases of time perception, then we observe that even invertebrates have a time perception which may also be quantified per intervals. So, if we refer to the so-called "triune brain" evolution model of Paul D. Maclean, along the biological line of evolution of living beings, one may argue on what possible changes have occurred along the human brain evolution from the rhombencephalic structures (typical of invertebrates), to mesencephalic ones (typical of mammals), until up prosencephalic components, above all their telencephalic parts, typical of human beings. Thus, we may infer that only these latter have conferred a more symbolic (or qualitative) meaning to time, besides its typical quantitative nature (which is a feature present, along the biological evolution line, from invertebrates to mammals), with the crucial passage from nature to culture. Hence, the above mentioned passage from the cyclic time to the linear one, with its enriched variety of meanings (culture), may be put into correlation with the rising of the neocortex structures.

Furthermore, having made reference to certain thermodynamical properties of complex dynamical systems 
to possibly explain human evolution, is also in agreement with some past hypotheses on the brain evolution based on the socalled radiator theory of brain due to the works of Dean Falk [12] and Konrad Fialkowski [13,14], where they put forward the main hypothesis according to which brain evolution of primitives might have been due to evolutionary adaptation responses to increased heat stresses and consequent temperature regulation which, in turn, entailed a rewiring of blood vessels net of human brain during its phylogenetic evolution. And the crucial role played by heat stress on human brain evolution has been supported by other studies carried out in the molecular biology context of gene expression [15], which might then be put into further consideration with the fact for which the presence of NBPF HORs (i.e., neuroblastoma breakpoint family gene higher order repeats) is what distinguishes human from chimpanzee brain [16]. Likewise, a further, interesting interdisciplinary research line should take into account some other outcomes of biology and dynamical system theory intertwinement, as those mentioned in $[17,18]$.

\section{Acknowledgment}

The author wishes to thank anonymous referees for having kindly provided very useful and remarkable insights and suggestions, which have been taken into account in this last revised form of such a very brief communication.

\section{References}

1. lurato G, Khrennikov AY. Entropy, externality and human evolution. Biosystems. 2020; 191-92: 104130.

PubMed: https://pubmed.ncbi.nlm.nih.gov/32173336/

2. Morelli R. Guarire senza medicine. La vera cura è dentro di te. Mondadori, Milano, 2012.

3. Galzigna L. La mente. Complessità e irriducibilità dell'attività mentale normale e patologica. Piccin, Padova. 2001.
4. Blanco M. Fondamenti di Neurosociologia. Primiceri Editore, Padova, 2016.

5. Oliverio A, Oliverio Ferraris, A. Lo sviluppo comparato del comportamento. Boringhieri, Torino, 1974.

6. Matarazzo $\mathrm{O}$, Zammuner $\mathrm{VL}$ (a cura di). La regolazione delle emozioni. II edizione, II Mulino, Bologna, 2015.

7. Fabbro F. Manuale di neuropsichiatria infantile. Una prospettiva psicoeducativa. Il edizione, Carocci, Roma, 2019.

8. Fabbro F. Le neuroscienze: dalla fisiologia alla clinica. Carocci, Roma, 2016.

9. Wagner H, Silber K. Psicologia fisiologica. II Mulino, Bologna, 2006.

10. Berardi N, Pizzorusso T. Psicobiologia dello sviluppo. Una introduzione. Editori Laterza, Roma-Bari, 2006.

11. Pinel JPJ, Barnes SJ. Psicobiologia. X edizione a cura di A. Facoetti, M. Ferrara, P. Marangolo, T. Pizzorusso, Edra, Milano, 2018.

12. Falk D. Brain evolution in Homo: The "radiator" theory. Behav Brain Sci. 1990; 13: 333-344.

13. Fialkowski RK. A Mechanism for the Origin of the Human Brain: A Hypothesis. Curr Anthropol. 1986; 27: 288-290.

14. Fialkowski RK. Heat stress as a factor in the preadaptive approach to the origin of the human brain. Behav Brain Sci. 1990; 13: 352-53.

15. Feliciello I, Akrap I, Ugarković Đ. Satellite DNA Modulates Gene Expression in the Beetle Tribolium castaneum after Heat Stress. PLoS Genet. 2015; 11: e1005466.

PubMed: https://pubmed.ncbi.nlm.nih.gov/26275223/

16. Paar V, Glunčić M, Rosandić M, Basar I, Vlahović I. Intragene Higher Order Repeats in Neuroblastoma BreakPoint Family Genes Distinguish Humans from Chimpanzees. Mol Biol Evol. 2011; 28: 1877-1892. PubMed: https://pubmed.ncbi.nlm.nih.gov/21273634/

17. Iurato G, Khrennikov AY. A Reader's Comment on: "Hysteresis Model of Unconscious-Conscious Interconnection: Exploring Dynamics on m-Adic Trees". p-Adic Numbers, Ultrametric Analysis and Applications. 2020; 12: 68-71.

18. Fedeli A. On two notions of topological entropy for noncompact spaces. Chaos, Solitons \& Fractals. 2009; 40: 432-435. 